\title{
Using IT for Distance Learning: Benefits and Challenges for African Learners
}

\section{Thierry Karsenti \\ Université de Montréal, Montréal, Québec, Canada}

Thierry.karsenti@umontreal.ca

\author{
Simon Collin \\ Université du Québec à \\ Montréal, Montréal, Québec, \\ Canada
}

\section{Collin.simon@uqam.ca}

\begin{abstract}
Open and distance learning (ODL) offers enormous potential for Africa, where higher education systems face numerous constraints. Yet few studies have addressed ODL in Africa. Against this background, this study aimed to 1) describe the profile of African students enrolled in an ODL program; 2) gain a deeper understanding of their experience with ODL. We used a mixed-method design, including an online questionnaire (to achieve objective 1) and individual interviews (to achieve objective 2) with two groups of participants: African students enrolled in an ODL program at the time of the study and African students who had completed an ODL program at the time of the study. Results indicate that both groups shared a similar sociological and technological profile and that ODL programs are taken as continuing education courses for purposes of professional development. It appears that the ODL experience resembles that of other students, particularly Western students. Few sociocultural aspects that were specific to Africa were found.
\end{abstract}

Keywords: ODL, Africa, perceptions, students.

NOTE: Only the abstract is being published in these proceedings.

Material published as part of this publication, either on-line or in print, is copyrighted by the Informing Science Institute. Permission to make digital or paper copy of part or all of these works for personal or classroom use is granted without fee provided that the copies are not made or distributed for profit or commercial advantage AND that copies 1) bear this notice in full and 2) give the full citation on the first page. It is permissible to abstract these works so long as credit is given. To copy in all other cases or to republish or to post on a server or to redistribute to lists requires specific permission and payment of a fee. Contact Publisher@InformingScience.org to request redistribution permission. 


\section{Biographies}

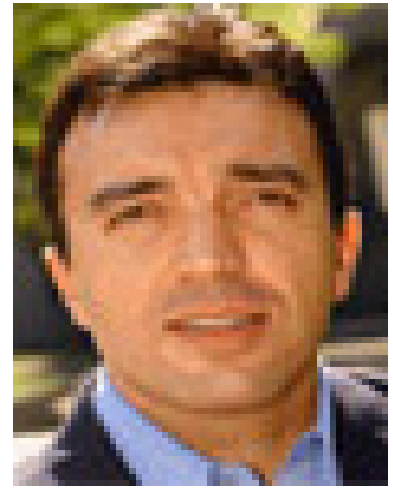

Thierry Karsenti, M.A., M.Ed., Ph.D., holds the Canada Research Chair on information and communication technologies (ICTs) in education. He is also a professor at the Université de Montréal, in the field of information and communication technologies and their integration in teacher training and education. He well, he was awarded the Prix d'Excellence en Conception Pédagogique by the Canadian Association of Distance Education (2000) and the Prix PEDAGOGICA-RESCOL for pedagogical innovation in the integration of ICTs (2000). In October 2000, he won the Prix quinquennal d'Excellence en enseignement and in 2008, he was awarded the Apple Distinguished Educator of the year (university level). He has also been recognized for his contributions, through research activities, to the quality of pedagogy. His research interests center upon the pedagogical integration of new technologies, teaching practices and motivation.

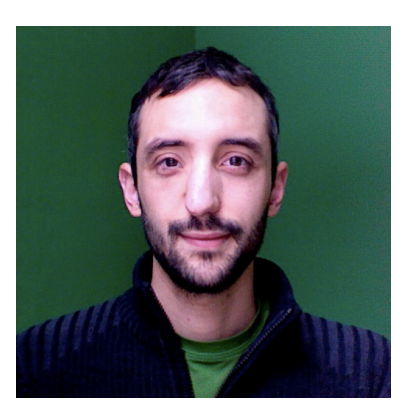

Simon Collin, M.Sc., Ph.D., is a professor in the Faculty of education of the University of Quebec in Montreal. He is also a research member of the Centre de recherche interuniversitaire sur la formation et la profession enseignante (CRIFPE). His academic training and his research interests center upon second language teaching and learning, Information and Communication Technologies (ICT) and immigration and ethnic minorities. He has already taken part in many national or international research projects and has published several academic and pedagogical works. 